\title{
Sistem Rekomendasi Destinasi Pariwisata Menggunakan Metode Hibrid Case Based Reasoning dan Location Based Service Sebagai Pemandu Wisatawan di Banyuwangi
}

\author{
${ }^{1}$ Dedy Hidayat Kusuma, ${ }^{2}$ Moh. Nur Shodiq \\ ${ }^{1,2}$ Teknik Informatika, Politeknik Negeri Banyuwangi \\ ${ }^{1,2}$ Banyuwangi, Indonesia \\ E-mail: 1'dedy@poliwangi.ac.id, 22shodiq@poliwangi.ac.id
}

Abstract - Sebagai salah satu destinasi wisata yang berkembang pesat, jumlah kunjungan wisatawan di Kabupaten Banyuwangi menunjukkan pertumbuhan yang cukup signifikan dimana pada rentang 2010 - 2015 te rjadi peningkatan wisatawan domestik sebesar $161 \%$ dan mancanegara sebesar $210 \%$. Peningkatan jumlah wisatawan tersebut bukanlah proses yang bebas dari masalah, terutama terkait preferensi kunjungan yang berubah seiring waktu. Informasi wisata dan minat wisatawan yang beragam seringkali membuat wisatawan kebingungan dalam menentukan pilihan tujuan wisata mana saja yang hendak dikunjungi. Sementara informasi wisata Banyuwangi yang tersedia dalam bentuk cetakan maupun yang bis a diakses secara online masih mengharuskan wisatawan untuk memilah dan memilih sendiri sesuai dengan minat dan preferensinya sehingga wisatawan memerlukan adanya saran atau rekomendasi. Dalam bidang pariwisata, rekomendasi ini bisa mencakup obyek yang hendak dikunjungi, event wisata yang ada, jadwal kunjungan, rute perjalanan, ketersediaan sarana prasarana dan sebagainya.

Sistem rekomendasi yang diusulkan dalam penelitian ini menggunakan kombinasi (hybrid) metode case-based reasoning dan location based. Sistem yang dibangun dalam bentuk aplikasi mobile berbasis android. Masukan dari pengguna untuk sistem berupa preferensi wisatawan meliputi je nis wisata, kategori tarif, moda transportasi, dan aktifitas wisata. Prefe rensi te rse but bersama dengan lokasi pengguna yang didasarkan pada koordinat GPS selanjutnya dibandingkan dengan atribut obyek wisata yang tersimpan pada sis tem dengan menggunakan metode similaritas nearest neighbor. Luaran sistem berupa rekomendasi obyek wisata yang memiliki similaritas tertinggi terhadap preferensi pengguna . Hasil penelitian ini diharapkan mampu membantu wisatawan dalam memilih obyek wisata di Banyuwangi sesuai dengan prefe rensi atau kriteria permintaannya.

Kata Kunci-Rekomendasi wisata, hybrid, CBR, location based 
Jurnal INTENSIF, Vol.1, No.1, Februari 2017

ISSN: $2549-6824$

\section{Pendahuluan}

Banyuwangi merupakan salah satu kabupaten di Propinsi Jawa Timur yang terletak di ujung timur Pulau Jawa. Data demografi menunjukkan secara umum Banyuwangi didominasi oleh Suku Jawa, Suku Madura, dan Suku Osing sehingga Banyuwangi kaya akan seni budaya dan adat tradisi. Secara geografis Kabupaten Banyuwangi memiliki garis pantai terpanjang di Jawa dan memiliki wilayah pegunungan yakni Pegunungan Ijen yang berada di sisi barat membentang dari arah utara selatan. Kondisi ini menyebabkan Banyuwangi memiliki obyek wisata alam yang beragam. Di sisi lain, lokasi Banyuwangi yang berdekatan dengan Pulau Bali menjadi salah satu peluang untuk menarik kedatangan wisatawan mancanegara yang berlibur di Pulau Bali. Potensi-potensi inilah yang kemudian dimanfaatkan oleh Pemerintah Kabupaten Banyuwangi yang berslogan "Sunrise of Java" untuk menggarap sektor pariwisata lebih baik.

Strategi yang diterapkan oleh Pemerintah Kabupaten Banyuwangi yang mengacu pada rencana strategis (Renstra) bidang pariwisata yaitu menjadikan daerah sebagai "produk" yang harus dipasarkan potensi wisatanya, memilih strategi pemasaran yang tepat, inovasi berkelanjutan, dan pengelolaan pariwisata melalui event Banyuwangi Festival [1].Strategi ini telah membuahkan beberapa penghargaan antara lain penghargaan Travel Club Tourism Award kategori The Most Improved pada tahun 2012, tahun 2013 meraih penghargaan TravelClub Tourism Award kategori The MostCreative dan pada tahun 2016 UNWTO Awards for Excellence and Innovation in Tourism untuk kategori Inovasi Kebijakan Publik dan Tata Kelola dari Organisasi Pariwisata Dunia Perserikatan Bangsa-Bangsa (UNWTO) dalam ajang "12th UNWTO Awards Forum" di Madrid, Spanyol [2].

Sebagai salah satu destinasi wisata yang berkembang, jumlah kunjungan wisatawan di Banyuwangi menunjukkan pertumbuhan yang cukup signifikan seperti ditunjukkan seperti pada Tabel 1. Peningkatan jumlah wisatawan tersebut bukanlah proses yang bebas dari masalah, terutama terkait preferensi kunjungan yang berubah seiring waktu. Informasi wisata dan minat wisatawan yang beragam seringkali membuat wisatawan kebingungan dalam menentukan pilihan tujuan wisata mana saja yang hendak dikunjungi [3]. Sementara informasi wisata Banyuwangi yang tersedia dalam bentuk cetakan maupun yang bisa diakses secara online masih mengharuskan wisatawan untuk memilah dan memilih sendiri sesuai dengan minat dan preferensinya sehingga wisatawan memerlukan adanya saran atau rekomendasi. Dalam bidang pariwisata, rekomendasi ini bisa mencakup obyek yang hendak dikunjungi, event wisata yang ada, jadwal kunjungan, rute perjalanan, ketersediaan sarana prasarana dan sebagainya [4]. 
Jurnal INTENSIF, Vol.1, No.1, Februari 2017

ISSN: 2549-6824

TABEL I. DATA KUNJUNGAN WISATAWAN

\begin{tabular}{cccc}
\hline \hline Jenis wisatawan & $\begin{array}{c}\text { Tahun 2010 } \\
\text { (orang) }\end{array}$ & $\begin{array}{c}\text { Tahun 2015 } \\
\text { (orang) }\end{array}$ & $\begin{array}{c}\text { Peningkatan } \\
(\%)\end{array}$ \\
\hline Asing & 13.200 & 41.000 & 210 \\
Domestik & 651.500 & 1.701 .230 & 161 \\
\hline
\end{tabular}

(Sumber: Dinas Pariwisata dan Kebudayaan Banyuwangi)

\section{Metode Penelitian}

Berdasarkan permasalahan tersebut maka dibutuhkan sebuah sistem yang mampu memberikan rekomendasi wisata. Sistem rekomendasi yang diusulkan dalam penelitian ini menggunakan kombinasi metode case-based reasoning (CBR) dan location based. Sistem yang dibangun nantinya dapat diakses wisatawan dalam bentuk aplikasi mobile. Masukan untuk sistem berupa preferensi wisatawan meliputi jenis wisata, kategori tarif, moda transportasi, aktifitas wisata, dan koordinat GPS wisatawan sedangkan luaran sistem berupa obyek wisata yang direkomendasikan. Hasil penelitian ini diharapkan mampu memberikan rekomendasi obyek wisata sesuai dengan preferensi atau kriteria permintaan wisatawan.

CBR didasarkan pada hipotesa bahwa solusi permasalahan-permasalahan sebelumnya dapat membantu penyelesaian permasalahan terkini, sepanjang terdapat kemiripan diantara mereka. Pengukuran kemiripan merupakan fase retrieval dalam siklus CBR dan dilakukan dengan membandingkan atribut yang ada pada kasus dengan atribut sejenis yang ada pada basis kasus. Suatu kasus disebut identik dengan kasus lain apabila nilai similaritasnya sama dengan satu, dan dikatakan mirip jika nilainya dibawah satu. Secara garis besar pengukuran similaritas terdiri dari pengukuran pengukuran similaritas lokal antar atribut kasus dan similaritas global antar kasus.

Secara garis besar alur sistem rekomendasi wisata yang dikembangkan diperlihatkan oleh Gambar 1 .

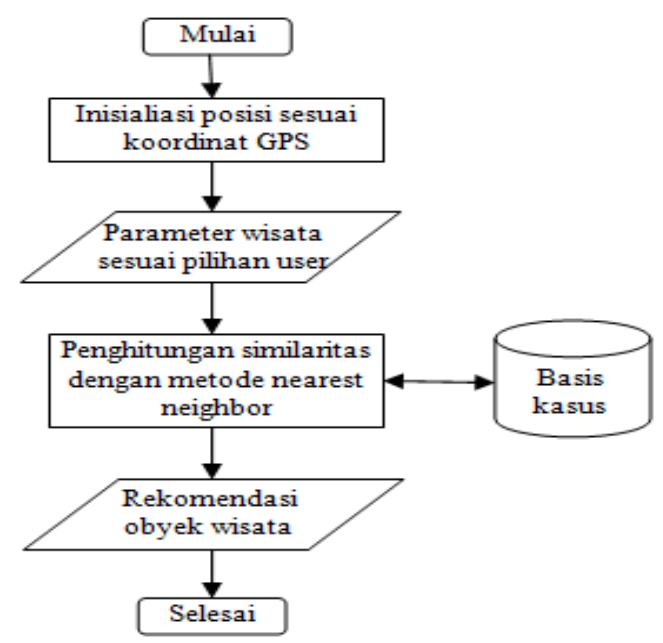

GAMBAR I. ALUR KERJA SISTEM 
Jurnal INTENSIF, Vol.1, No.1, Februari 2017

ISSN: $2549-6824$

\section{Hasil \& Pembahasan}

Sebuah kasus haruslah direpresentasikan ke dalam suatu bentuk tertentu untuk kepentingan penyimpanan dalam basis kasus dan proses retrieval[5]. Representasi dari sebuah kasus haruslah mencakup permasalahan yang menjelaskan keadaan yang dihadapi dan solusi yang merupakan penyelesaian kasus tersebut. Model representasi yang digunakan yaitu model flat frame. Permasalahan dalam penelitian ini direpresentasikan melalui 5 fitur sebagaimana diperlihatkan pada Tabel 2.

TABEL II. JENIS DAN PENILAIAN ATRIBUT

\begin{tabular}{ll}
\hline \hline \multicolumn{1}{c}{ Atribut } & \multicolumn{1}{c}{ Nilai } \\
\hline Jenis wisata & Alam; Religi; Budaya; Kota; Buatan; Kerajinan \\
Kategori tarif & 1.Gratis; 2.Murah; 3.Sedang; 4.Mahal \\
Moda transportasi & 1. Motor 2. Mobil; 3.Bus \\
Aktifitas wisata & Refreshing; Petualangan; Bermain \\
Lokasi & Koordinat GPS \\
\hline
\end{tabular}

Pembahasan terhadap hasil penelitian dan pengujian yang diperoleh disajikan dalam bentuk uraian teoritik, baik secara kualitatif maupun kuantitatif. Hasil percobaan sebaiknya ditampilkan dalam berupa grafik atau pun tabel. Untuk grafik dapat mengikuti format untuk diagram dan gambar.

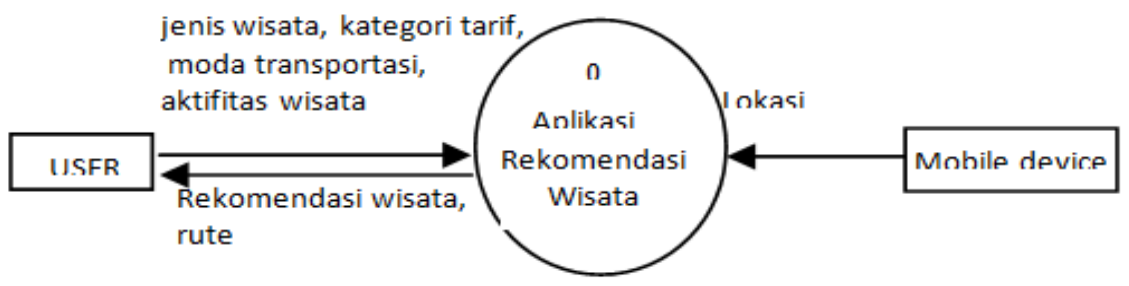

\section{GAMBAR II. CONTEXT DIAGRAM}

Atribut lokasi diperlukan untuk menghitung jarak antara koordinat obyek wisata dengan koordinat mobile device pengguna. Diasumsikan pengguna berada di wilayah Kabupaten Banyuwangi sehingga pengaruh lengkung bumi terhadap jarak geografis diabaikan. Penghitungan jarak koordinat menggunakan persamaan phytagoras (1).

$$
d(S, T)=\sqrt{\left(x_{g}-x_{\mathrm{t}}\right)^{2}+\left(\mathrm{y}_{s}-y_{\mathrm{t}}\right)^{2}}
$$

Keterangan:

$d\left(S_{i}, T_{i}\right) \quad$ : Jarak antara koordinat pengguna $\mathrm{S}$ dengan obyek wisata $\mathrm{T}$

$x_{g} \quad$ : Posisi lintang pengguna $\mathrm{S}$

$x_{g} \quad:$ Posisi lintang obyek wisata $\mathrm{T}$

$y_{s} \quad$ : Posisi bujur pengguna $\mathrm{S}$

yt $\quad$ : Posisi bujur obyek wisata $\mathrm{T}$ 
Similaritas lokal menunjukkan keserupaan antara atribut permasalahan terhadap atribut yang sama dari sebuah kasus. Persamaan (2) digunakan untuk menghitung nilai similaritas lokal [6] pada atribut kategori tarif dan jarak yang merupakan atribut turunan dari lokasi.

$$
f_{i}\left(S_{i}, T_{i}\right)=1-\frac{\left\|S_{i}-T_{i}\right\|}{\max \left(S_{i} T_{i}\right)-\min \left(S_{i} T_{i}\right)}
$$

Keterangan:

$f_{i}\left(S_{i}, T_{i}\right) \quad$ : Similaritas lokal atribut ke-i antara source case dan atribut target case

$S_{i} \quad:$ Atribut ke-i dari source case

$T_{i} \quad:$ Atribut ke-i dari target case

$\max \left(S_{i}, T_{i}\right)$ : Nilai maksimum atribut ke-i antara source case dan atribut target case

$\min \left(S_{i}, T_{i}\right)$ : Nilai minimum atribut ke-i antara source case dan atribut target case

Similaritas lokal untuk moda tansportasi menggunakan persamaan (3).

$$
f_{i}\left(S_{i}, T_{i}\right)=\left\{\begin{array}{lr}
1_{s} & s \geq t \\
1-\frac{\left|S_{i}-T_{i}\right|}{\max \left(S_{i}, T_{i}\right)-\min \left(S_{i}, T_{i}\right)}, & \text { lainnya }
\end{array}\right.
$$

Sedangkan untuk menghitung similaritas lokal pada atribut jenis wisata dan aktifitas wisata digunakan persamaan (4) [7].

$$
f_{i}\left(S_{i}, T_{i}\right)= \begin{cases}1 & \text { jitha } g=t \\ 0 & \text { lainny }\end{cases}
$$

Nilai similaritas lokal yang diperoleh selanjutnya digunakan untuk mendapatkan similaritas global antara kasus preferensi pengguna dengan kasus yang tersimpan dalam basis kasus sistem menggunakan metode similaritas nearest neighbor[8] dikali dengan similaritas jarak untuk mendapatkan korelasi[9] seperti pada persamaan (5).

$$
\operatorname{Sim}(S, T)=\left(\frac{\sum_{i=1}^{n} f\left(S_{i} T_{i}\right) * W_{i}}{\sum_{i=1}^{n} W_{i}}\right) * f_{a}
$$

Keterangan:

$\operatorname{Sim}(S, T)$ : Similaritas global antara source case $S$ dan target case $T$

$n \quad$ : Banyaknya atribut

$S_{i} \quad:$ Atribut ke-i dari source case

$T_{i} \quad:$ Atribut ke-i dari target case

$w_{i} \quad:$ Bobot atribut ke- $i$

$f\left(S_{i}, T_{i}\right)$ : Similaritas lokal atribut ke-i dari source case dan target case

$f_{d} \quad$ : similaritas jarak

Dalam penelitian ini tiap atribut memiliki bobot yang berbeda untuk setiap jenis solusi yang nilainya didasarkan pada hasil survei yang dilakukan kepada 50 responden. Selain mampu memberikan rekomendasi wisata, aplikasi yang dibangun ini memiliki fitur tambahan berupa informasi obyek wisata, galery foto, hotel, dan kuliner seperti diperlihatkan pada Gambar 3. 
Jurnal INTENSIF, Vol.1, No.1, Februari 2017

ISSN: 2549-6824
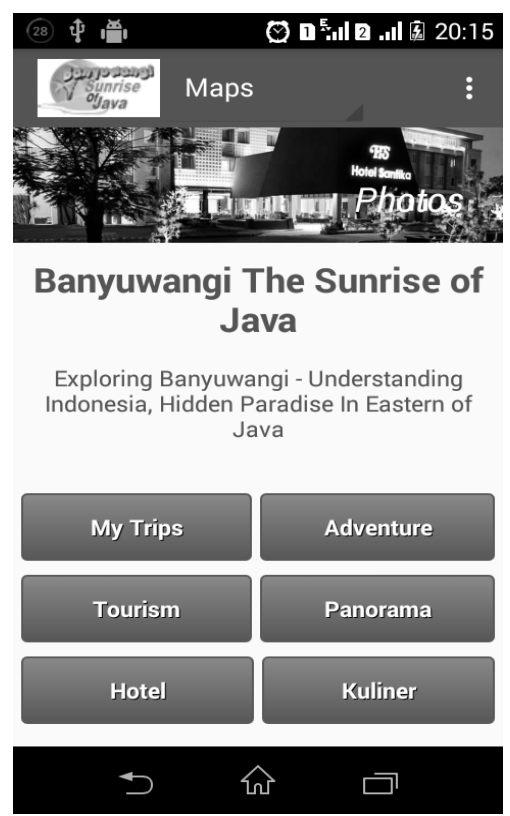

GAMBAR III. TAMPILAN MUKA APLIKASI

\section{KeSimpulan \& SARAN}

Penelitian ini menghasilkan sebuah program aplikasi mobile berbasis android yang mampu memberikan rekomendasi destinasi pariwisata dengan mempertimbangkan kriteria preferensi yang dipilih pengguna serta lokasi pengguna yang diperoleh dari koordinat aktif GPS perangkat yang digunakan.

Data basis kasus yang digunakan masih bersifat statis atau tersimpan dalam bundling aplikasi sehingga penambahan obyek wisata baru hanya dimungkinkan dengan melakukan update aplikasi. Pengembangan aplikasi dapat dilakukan dengan menambahkan web service ataupun layanan berbasis web sehingga data basis kasus dapat diakses secara real time dan dapat dilakukan perubahan setiap saat tanpa perlu melakukan update aplikasi.

\section{Daftar Pustaka}

[1] Dinas Kebudayaan Dan Pariwisata Kabupaten Banyuwangi .2010. Rencana Strategis( Renstra). Diakses dari http://banyuwangikab.go.id/media/perencanaan_anggaran/pdf/dispar_renstra_ dispar_Th_2010_2015.docx pada tanggal 14 April 2016 jam 10:00.

[2] Berita Banyuwangi. Diakses dari http:banyuwangikab.go.id. pada tanggal 14 April2016 jam 10:15.

[3] Widodo,S., dan Utomo, V.G. 2014.Rancang Bangun Aplikasi Travel Recommender Berbasis Wap Menggunakan Metode Fuzzy Model Tahani (Studi Kasus Di Kota Semarang). Jurnal Teknologi Informasi dan Komunikasi, ISSN : 2087 - 0868, Volume 5 Nomor 1 Maret 2014 
[4] Petrevska, B., dan Koceski, S. 2012. Tourism Recommendation System: Empirical Investigation. Journal of tourism. [Issue 14]

[5] Pal, S.K., dan Shiu, S.C.K., 2004, Fondation of Soft Case-Based Reasoning, John Willey and Sons, Inc., New Jersey

[6] Shi, H., Xin, M., Dong, W., 2011, A Kind of Case Similarity Model Based on Case-Based Reasoning, International Conferences on Internet of Things, and Cyber, Physical and Social Computing IEEE, 453-457

[7] Nurdiansyah, Y., dan Hartati, S., 2014, Case-Based Reasoning untuk Pendukung Diagnosa Gangguan pada Anak Autis, Tesis, Prodi S2/S3 Ilmu Komputer JIKE FMIPA UGM, Yogyakarta

[8] Hastie, T., Tibshirani, R., dan Friedman, J., 2009, The Element of Statistical Learning : Data Mining, Inference, and Prediction, Springer Series in Statistic, 2, Springer-Verlag, Inc., New York

[9] Røine, P.C. 2011. Design and Evaluation of a Personalized Mobile Tourist System. Thesis. Norwegian University of Science and Technology Department of Computer and Information Science 